Original Research Article

\title{
Quantification of rutin and quercetin by HPTLC/HPLC and in vitro immunomodulatory and anticancer activities of Capparis moonii fruits extracts
}

\author{
Gaurav Mahesh Doshi ${ }^{1 *}$, Manjushree Kundalik Pawar ${ }^{2}$, Kajal Haribhai Chavda ${ }^{2}$
}

\begin{abstract}
${ }^{1}$ Department of Pharmacology,
${ }^{2}$ Department of Quality

Assurance, Vivekanand

Education Society's College of

Pharmacy, Chembur, Mumbai,

Maharashtra, India

Received: 13 November 2017

Accepted: 04 December 2017

*Correspondence to:

Dr. Gaurav Mahesh Doshi,

Email: gaurav.pharmacology

@gmail.com
\end{abstract}

Copyright: (C) the author(s), publisher and licensee Medip Academy. This is an openaccess article distributed under the terms of the Creative Commons Attribution NonCommercial License, which permits unrestricted noncommercial use, distribution, and reproduction in any medium, provided the original work is properly cited.

\begin{abstract}
Background: The current research was undertaken on dried fruits of Capparis moonii to screen its potential for immunomodulatory and cancer indications with identification of phytoconstituents by chromatographic techniques.

Methods: Methanolic (MECN), hydro-methanolic (HMECN) and aqueous extracts (AQCN) of Capparis moonii were subjected to high performance thin layer chromatography (HPTLC) and high-performance liquid chromatography (HPLC) after studying the total phenolic and flavonoid content by using rutin and gallic acid as standards respectively as well as undertaking powder characteristics and preliminary phytochemical screening. Immunomodulatory activities covered were hemagglutination antibody titre and delayed-type hypersensitivity reaction with the aid of sheep red blood cells $(0.5 \times 109)$ as antigens. The extracts were studied for antioxidant potential. Anticancer prospects were focusing on in vitro cell lines screening (MCF 7 and HCT 15) by Sulforhodamine B assay method and potato disc assay.

Results: The total phenolic and flavonoid content of MECM, HMECM and AQCM fruits extracts were found to be $0.20,0.11$ and $0.47 \mathrm{mg}$ of gallic acid/g and 78.3, 18.8 and $64.4 \mathrm{mg}$ of rutin/g respectively. Rutin and quercetin were confirmed by HPTLC and HPLC showing well resolved peaks. IC50 values in antioxidant studies were found to be significant with all the extracts. Significant immunomodulatory effect was noticed at $200 \mathrm{mg} / \mathrm{kg}$ in both models (high antibody titre levels and decrease paw volume after $48 \mathrm{~h}$ ). Unsatisfactory results were observed with selected cell lines and disc assay.

Conclusions: Thus, selected fruits may probably have immunomodulatory potential due to presence of flavonols (rutin and quercetin).
\end{abstract}

Keywords: Capparis moonii, Delayed-type hypersensitivity, Haemagglutination antibody titre, Potato disc assay, Sulforhodamine B assay method

\section{INTRODUCTION}

Medicinal plants having ethnopharmacological relevance are been used since decades for treatment due to their phytoconstituents. Synthetic molecules pose multiple problems even leading to death. ${ }^{1}$

Witnessing the thrust area of immunology as the emerging field of research, the team has propagated the work in this paper.
Secondary immunodeficiencies are consequences caused by cytotoxic drugs, malnutrition, infections and metabolic disorders resulting in specific and nonspecific immunity e.g. cancer, AIDS etc. ${ }^{2}$ Cancer is a disease characterized by uncontrolled multiplication of normal cells. As per Indian population census, rate of mortality due to cancer was alarming with about $8,06,000$ existing cases by the end of last century. Developed countries have now changed their paradigm towards exploring herbal medicine. ${ }^{3}$ As one-third population actually lack access to essential 
lifesaving drugs, herbal therapies could provide a major breakthrough.

In Ayurvedic, plants considered under family Capparidaceae have been known for their immense rasayana property. Few of the widely studied plants are $C$. sepiaria, C. spinosa, C. tomentosa, C. zeylanica and Capparis moonii (CM). CM has been regarded as Rasayani, Shoshghani, Jara Vinashnam and Rajyakshma Shasyate for its therapeutic usefulness. The components present in the fruits are $\beta$-sitosterol, stachyhydrin, chebulinic acid derivatives and gallotannins. It has been reported for antitussive, antibacterial, hepatotoxicity and in vitro immunomodulatory activities. ${ }^{4}$

The selected family of plants is used in tuberculosis, rheumatism, cancer and diabetes but still elaborative research is required in other pharmacological fields. ${ }^{5}$ In purview of above literature, the research group has attempted to study $\mathrm{CM}$ fruits extracts for their immunomodulatory and anticancer effects with supported phytochemical quantification of flavonols by UV, HPTLC and HPLC (Figure 1).

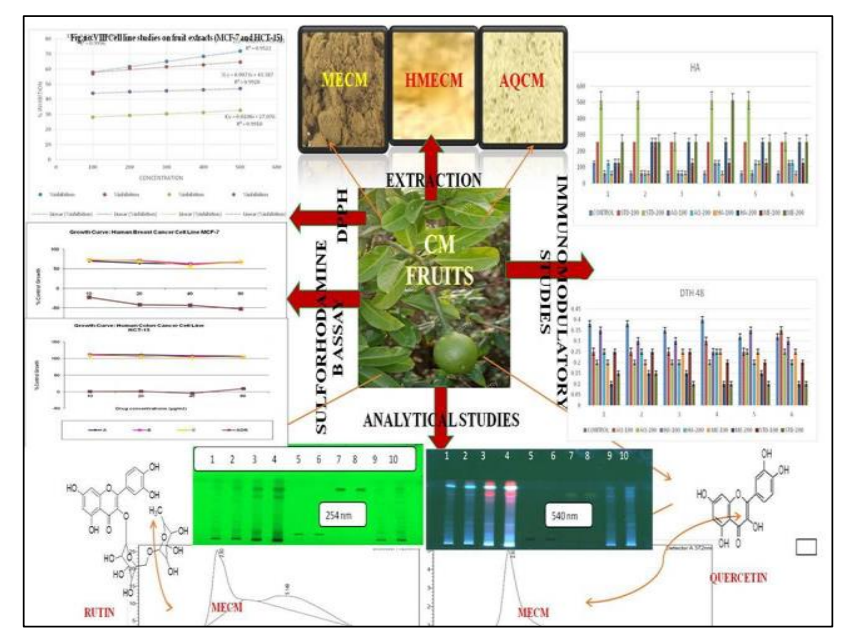

Figure 1: CM fruits extracts graphical abstract.

\section{METHODS}

\section{Collection, authentication and extraction of CM fruits}

The fruits of the healthy shrub were purchased from local market, Mumbai in May-June and dried in shade. The plant was authenticated at the Agharkar Research Institute, Pune, India. [Voucher specimen no. 138/15]. The dried fruits were grounded into coarse powder using a grinder which was subjected to three different extraction procedures (MECN, HECM and AECM) mentioned below and were stored at $2-8^{\circ} \mathrm{C}$. The dried extracts were subjected to powder characteristics, flavonoid and phenolic estimation, TLC (Thin layer Chromatography), HPTLC (High Performance Thin Layer Chromatography) and HPLC (High Performance Liquid Chromatography) quantification followed by immunomodulatory and cell line studies.

\section{Methanolic extract of Capparis moonii (MECM)}

The powder was macerated in an extraction bottle using methanol $(100 \mathrm{~g}$ in $500 \mathrm{ml})$, kept in dark place at room temperature for 10-15 days with intermittent shaking. On the $16^{\text {th }}$ day, the extract was filtered, and the residue was collected was dried at $60^{\circ} \mathrm{C}$ on water bath in evaporating dish.

\section{Hydromethanolic extract of Capparis moonii (HMECM)}

The powder was extracted by soxhlet extraction at $55^{\circ} \mathrm{C}$ with methanol and water $(60: 40)$. $50 \mathrm{~g}$ pouch in $200 \mathrm{ml}$ was suspended in soxhlet thimble. The extract obtained in round bottom flask was filtered, evaporated and dried at $75^{\circ} \mathrm{C}$ on water bath in evaporating dish.

\section{Aqueous extract of Capparis moonii (AECM)}

The powder was extracted at $100{ }^{\circ} \mathrm{C}$ on water bath with demineralized water (50 $\mathrm{g}$ suspended in $500 \mathrm{ml}$ ). The extract was filtered with sintered glass filter, dried by applying vacuum pressure at 100 psi.

\section{Determination of powder characteristics}

$\mathrm{CM}$ fruits extracts were subjected to total ASH value, acid insoluble ash, water soluble extractive, ethanol soluble extractive, total solid content and loss on drying. ${ }^{6}$

\section{Preliminary phytochemical screening}

$\mathrm{CM}$ fruits extracts were studied for preliminary phytochemical screening. ${ }^{7}$

\section{Total flavonoid and phenolic estimation}

The amount of total phenolic and flavonoid contents in the $\mathrm{CM}$ fruits extracts were measured using rutin and gallic acid as standards respectively. ${ }^{8}$ Results were expressed as rutin and gallic acid equivalents in $\mathrm{mg} / \mathrm{gm}$.

\section{Analytical studies}

\section{$T L C$}

In $\mathrm{CM}$ fruits extracts, mobile phases of methanol/chloroform/glacial acetic acid (1.5:2.5:1) and methanol/glacial acetic acid/formic acid/water (3:1.5:0.9:0.5) were used for identification of rutin and quercetin respectively. The standard and extract samples were dissolved in the methanol $(10 \mathrm{mg}$ in $1 \mathrm{ml})$ and were filtered through Whatman filter paper no.1 before spotting on the plates, exposed to ammonia and visualized under UV lamp. ${ }^{9,10}$ 


\section{HPTLC}

Standard $(7 \mathrm{mg} / 7 \mathrm{ml}$ of rutin and $5 \mathrm{mg} / 5 \mathrm{ml}$ of quercetin) and fruit extracts $(200 \mathrm{mg} / 5 \mathrm{ml})$ were dissolved in methanol. Quantification was done by application of the spots on HPTLC plate which were coated with silica gel (plate size of $20.0 \times 10.0 \mathrm{~cm}$ ). The mobile phase used was ethyl acetate/formic acid/glacial acetic acid/water (10:0.5:0.5:1.3). The plates were developed at $254 \mathrm{~nm}$ under UV visible wavelength but well resolved spots with images were obtained only after derivatization at $540 \mathrm{~nm}$. The details of the instrument used in studies was CAMAG LINOMAT 5 with 5 application parameters, inert gas (nitrogen) as spray gas, methanol as sample solvent with dosage speed $150 \mathrm{nl} / \mathrm{s}$ and pre-dosage volume $0.2 \mu 1$. Syringe size was $100 \mu \mathrm{l}$ with 10 tracks, $8 \mathrm{~mm}$ application position and $8 \mathrm{~mm}$ band length. The calibration parameters used was calibration mode multilevel, with CV statistics mode and the evaluation mode was based on peak areas. The results were calculated using single point calibration method for CM fruits extracts. The studies were undertaken at Anchrom Test Lab Pvt. Ltd., Mumbai.

Formula: Response factor $=$ peak area of standard/Standard amount

\section{HPLC}

CM fruits extracts $(5 \mathrm{mg} / 5 \mathrm{ml})$ and standard $(5 \mathrm{mg} / 5 \mathrm{ml})$ were dissolved in methanol. Mobile phases used were water/acetonitrile/5\% glacial acetic acid/methanol (75:10:5:10) and methanol/acetonitrile/phosphate buffer (pH 3) (42.5:42.5:15) for rutin and quercetin respectively. The column dimensions were C-18, 250 X 4.6mm X 5mm with flow rate of $1 \mathrm{ml} / \mathrm{min}$, run time of $10 \mathrm{~min}$ and injection volume of $20 \mu 1$. Results were analysed by calibration curve, single point calibration method.

Formula: $\%$ of constituent $=$

\section{Area of sample $\mathrm{x}$ standard dilution $\mathrm{x}$ purity $\times 100$ Area of standard $x$ sample dilution}

\section{Standard drugs and chemicals}

Ashwangandha churna is well known for its immunomodulatory potential in literature. ${ }^{11}$ Ashwagandha churna (Dabur, India Ltd.) was used as a standard procured from local retailer supplier. Standard biomarkers (rutin and quercetin) from Sigma Aldrich Private Limited, Mumbai and all the chemicals used throughout the research were procured from local suppliers.

\section{Preparation of antigens, standard and extracts}

Fresh blood was collected from sheep sacrificed in the local slaughter house. Sheep red blood cells (SRBCs) were washed three times in large volumes of pyrogen free $0.9 \%$ normal saline and adjusted to a concentration of $0.5 \times 109$ cells/ml for immunization and challenge. ${ }^{12}$ Before dosing,
CM fruits extracts and the standard were dissolved in $0.5 \%$ carboxy methyl cellulose.

\section{Animal studies}

Albino Wistar rats of either sex (120-150gm) were procured from Bharat Serums and Vaccines Ltd., Mumbai. Based on the body weight, dosing was done per oral route (p.o). The groups in studies are as follows:

- Group I: Served as control $(0.5 \%$ sodium CMC solution at $1 \mathrm{mg} / \mathrm{kg}$ ).

- Group II, IV and VI: MECM, HMECM and AQCM extracts $(100 \mathrm{mg} / \mathrm{kg})$.

- Group III, V and VII: MECM, HMECM and AQCM extracts $(200 \mathrm{mg} / \mathrm{kg})$.

- Group VIII and IX: Ashwagandha churna (100mg/kg and $200 \mathrm{mg} / \mathrm{kg}$ ).

\section{Experimental conditions}

Rats were maintained under $12 \mathrm{~h}$ of light and dark cycles at temperature $22 \pm 1^{\circ} \mathrm{C}$ and relative humidity $65 \pm 10 \%$. They were housed in groups of 3 in rectangular cages made from plastic Pyrex with paddy husk bedding and fed with standard pellet food. The animals were fasted approximately $16 \mathrm{~h}$ before study with free access to water.

\section{Acute toxicity studies}

The studies were undertaken as per OECD guidelines 423. ${ }^{13}$ Female rats were administered a single dose at $2000 \mathrm{mg} / \mathrm{kg}$. The following conditions were recorded.

\section{Mortality/viability/clinical signs/body weights}

It was recorded for first $30 \mathrm{~min}$ and at 1, 2, 3 and $4 \mathrm{~h}$ after administration of $\mathrm{CM}$ fruits extracts on test day 0 (in common with the clinical signs) and twice daily during the acclimatization period (at least once on day of sacrifice). Body weights were determined on test days 0 (prior to administration) and on day 7 and day 14 .

\section{Animal models $3,14,15$}

\section{Hemagglutination antibody (HA) titre}

Immunization was induced by $0.1 \mathrm{ml}$ of SRBCs suspension containing $0.5 \times 109$ cells intraperitoneally on day 0 . Control, CM fruits extracts and standard were given orally for 7 days. On the $7^{\text {th }}$ day, by retro-orbital puncturing technique, blood samples were collected in microcentrifuge tubes, followed by centrifugation and the serum was pooled from each group. A two-fold serial dilution of pooled serum samples were made in $25 \mu 1$ volumes of normal saline in microtitration plates and to it was added to $25 \mu \mathrm{l}$ of $1 \%$ suspension of SRBCs in saline. Hemagglutination was observed under the microscope after incubation of the plates at $37^{\circ} \mathrm{C}$ for $1 \mathrm{~h}$. Reciprocal of 
the highest dilution of the test serum agglutination was treated as antibody result.

\section{Delayed-type hypersensitivity (DTH) response $e^{3,14,15}$}

Right hind foot pad was encountered with $0.5 \times 10^{9} \mathrm{SRBCs}$ cells. After +24 and $+48 \mathrm{~h}$ of this treatment period, foot thickness was monitored with vernier calipers.

Control, CM fruits extracts and standard were administered from 0 to $7^{\text {th }}$ day. The treated foot measurement was done on $7^{\text {th }}$ (prior to injection), 8th and 9th day. Difference between prior and post injection footpad thickness was noticed as DTH response.

\section{Statistical analysis}

The values were expressed as mean \pm SEM and $* \mathrm{p}<0.05$, $* * \mathrm{p}<0.01, * * * \mathrm{p}<0.001$ and $* * * * \mathrm{p}<0.0001$ by applying one-way analysis of variance (ANOVA) followed by Dunnett test using Graph Pad Prism version of 6.

\section{Antioxidant studies}

CM fruits extracts $(0.2 \mathrm{ml})$ were diluted with methanol and $2 \mathrm{ml}$ of DPPH (1-Diphenyl-2-picrylhydrazyl) solution $(0.5 \mathrm{mM})$ were added. After $30 \mathrm{~min}$, the absorbance was measured at $517 \mathrm{~nm}$. A graph of percent inhibition v/s concentration was plotted. ${ }^{16}$

\section{In vitro screening of the extracts using cell lines ${ }^{1,17,18}$}

The cell cultures and media consist of human colon cancer cell line HCT15, human breast cancer cell line MCF7 and standard drug Adriamycin (Doxorubicin) which were procured and maintained at ACTREC, Kharghar, Mumbai. The cell lines were grown in Roswell Park Memorial Institute (RPMI) 1640 medium containing $10 \%$ fetal bovine serum and $2 \mathrm{mM}$ L-glutamine.

For CM fruits screening, cells were inoculated into 96 well microtiter plates in $100 \mu \mathrm{L}$ at plating densities, depending on the doubling time of individual cell lines. After cell inoculation, the microtiter plates were incubated at $37{ }^{\circ} \mathrm{C}$, $5 \%$ with carbon dioxide, $95 \%$ air and $100 \%$ relative humidity for $24 \mathrm{~h}$ prior to addition. The extracts were initially solubilized in dimethyl sulfoxide at $100 \mathrm{mg} / \mathrm{ml}$, diluted to $1 \mathrm{mg} / \mathrm{ml}$ using water and stored frozen prior to use. At the time of drug addition, an aliquot of frozen concentrate $(1 \mathrm{mg} / \mathrm{ml})$ was thawed and diluted to 100,200 , 400 and $800 \mu \mathrm{g} / \mathrm{ml}$ with complete medium containing the $\mathrm{CM}$ fruit extracts. Aliquots of $10 \mu \mathrm{l}$ of these different drug dilutions were added to the appropriate microtiter wells already containing $90 \mu \mathrm{l}$ of medium, resulting in the required final drug concentrations i.e. 10, 20, 40 and $80 \mu \mathrm{g} / \mathrm{ml}$.

After addition of CM fruits extracts and standard, the plates were incubated at standard conditions for $48 \mathrm{~h}$ and the assay was terminated by addition of cold TCA (trichloroacetic acid). Cells were fixed in situ by the gentle addition of $50 \mu \mathrm{l}$ of cold $30 \%(\mathrm{w} / \mathrm{v})$ TCA (final concentration, $10 \% \mathrm{TCA}$ ) and incubated for $60 \mathrm{~min}$ at $4{ }^{\circ} \mathrm{C}$. The supernatant was discarded; the plates were washed five times with tap water and air dried. Sulforhodamine B (SRB) solution $(50 \mu \mathrm{l})$ at $0.4 \%(\mathrm{w} / \mathrm{v})$ in $1 \%$ acetic acid was added to each of the wells and the plates were incubated for $20 \mathrm{~min}$ at room temperature.

After staining, the unbound dye was recovered, and the residual dye was removed by washing five times with $1 \%$ acetic acid. The plates were air dried. Bound stain was subsequently eluted with $10 \mathrm{mM}$ trizma base and the absorbance was read on a plate reader at a wavelength of $540 \mathrm{~nm}$ with $690 \mathrm{~nm}$ as reference wavelength. Percent growth was calculated on a plate-by-plate basis for test wells relative to control wells. Percent growth was expressed as:

Formula: $\%$ growth $=\mathrm{Ti} / \mathrm{C} \times 100$

By using the six absorbance measurements [time zero $(\mathrm{Tz})$, control growth $(\mathrm{C})$, and test growth in the presence of drug at the four concentration levels (Ti)]

\section{Potato disc assay method on CM fruits ${ }^{19}$}

Russet potatoes were obtained from local grocery store. They were washed, peeled and immersed in sodium hypochlorite for $2 \mathrm{~min}$. Different concentration of standard and CM fruits extracts were prepared. 5\% DMSO was used as control solution. $1 \mathrm{ml}$ of $1.5 \%$ agar solution was transferred into a culture plate. Potato disc were kept in center of culture plate submerged nearly $2 / 3^{\text {rd }}$ in agar solution. By using sterile micropipettes bacterial (Agrobacterium tumefaciens) solution, standard or control solutions were mixed, and each potato disc was incubated after applying 1 drop of test or control solution. After 7-21 days potato discs were analysed by using Lugol's solution.

\section{RESULTS}

\section{Percent yield of the extracts}

The maximum extraction yield of dried CM fruits extracts (MECM, HMECM and AQCM) was found to be 20, 32 and $38 \%$ w/w respectively.

\section{Powder characteristics of extracts}

The total Ash value, acid insoluble ash, water extractive value, ethanol extractive value, total solid content and loss on drying for CM fruits extracts were found to be $6.4,0.5$, $26.5,9.4,26.6$ and $15.4 \% \mathrm{w} / \mathrm{v}$ respectively.

\section{Preliminary phytochemical screening}

CM fruits extracts were found to be present positive for flavonoids, steroids, alkaloids, saponins, glycoside, tannins and phenolic compounds, fats and oils. 


\section{Total phenolic and flavonoid content}

The total phenolic and flavonoid content of MECM, HMECM and AQCM fruits extracts were found to be 0.20 ,
0.11 and $0.47 \mathrm{mg}$ of gallic acid/gm and 78.3, 18.8 and $64.4 \mathrm{mg}$ of rutin/gm respectively.

Table 1: HPTLC analysis on CM fruits extracts.

\begin{tabular}{|llllll|}
\hline $\begin{array}{l}\text { Track } \\
\text { No }\end{array}$ & $\begin{array}{l}\text { Application } \\
\text { position }\end{array}$ & $\begin{array}{l}\text { Application } \\
\text { volume }\end{array}$ & $\begin{array}{l}\text { Details of standard and } \\
\text { sample }\end{array}$ & $\begin{array}{l}\text { Maximum } \mathbf{R}_{\mathbf{f}} \\
\text { value }\end{array}$ & Area \\
\hline 4 & $73.1 \mathrm{~mm}$ & $20.0 \mu \mathrm{l}$ & MECM (quercetin) & 0.78 & 9785.2 \\
\hline 2 & $37.7 \mathrm{~mm}$ & $20.0 \mu \mathrm{l}$ & HMECM (quercetin) & 0.80 & 2863.9 \\
\hline 9 & $161.6 \mathrm{~mm}$ & $10.0 \mu \mathrm{l}$ & AQCM (quercetin) & 0.80 & 2319.2 \\
\hline 8 & $143.9 \mathrm{~mm}$ & $2.0 \mu \mathrm{l}$ & Standard quercetin & 0.78 & 10599.5 \\
\hline 5 & $90.8 \mathrm{~mm}$ & $2.0 \mu \mathrm{l}$ & Standard rutin & 0.09 & 5844.5 \\
\hline 4 & $73.1 \mathrm{~mm}$ & $20.0 \mu \mathrm{l}$ & MECM (rutin) & 0.12 & 3288.2 \\
\hline 2 & $37.7 \mathrm{~mm}$ & $20.0 \mu \mathrm{l}$ & HMECM (rutin) & 0.09 & 3106.1 \\
\hline 9 & $161.6 \mathrm{~mm}$ & $10.0 \mu \mathrm{l}$ & AQCM (rutin) & 0.09 & 1754.9 \\
\hline
\end{tabular}

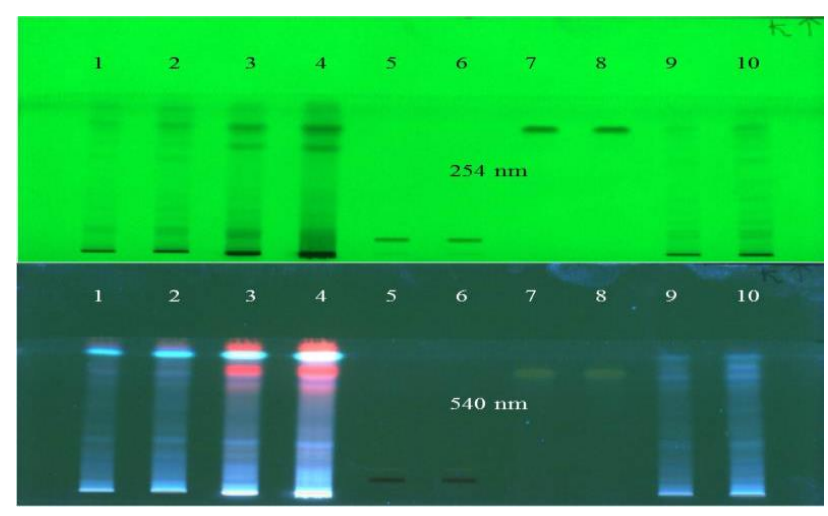

Figure 2: HPTLC analysis on CM fruits.

\section{Analytical studies}

$T L C$

$\mathrm{R}_{\mathrm{f}}$ values were found to be 0.79 (MECM), 0.77 (HMECM) and 0.74 (AQCM) in comparison to the standard rutin

\section{HPLC}

having 0.79. Quercetin was found to have $\mathrm{R}_{\mathrm{f}}$ values of 0.63 (MECM), 0.66 (HMECM) and 0.66 (AQCM) in comparison to the standard 0.64 for $\mathrm{CM}$ fruits extracts.

\section{HPTLC}

CM fruits extracts has shown well resolved spots at tracks 1-4 and 9, 10 in comparison to standard rutin (tracks 5, 6) and quercetin (tracks 7,8 ). Maximum $\mathrm{R}_{\mathrm{f}}$ value was found to be MECM (0.14), HMECM (0.12) and AQCM (0.12) in comparison with standard rutin at 0.09 . The results were found to be $8.4,3.6$ and $2.8 \% \mathrm{w} / \mathrm{w}$ respectively. Maximum $\mathrm{R}_{\mathrm{f}}$ value of MECM (0.80), HMECM (0.78) and AQCM (0.80) was found comparable with standard rutin at 0.78 .
The results were found to be $0.8,1.4$ and $1.1 \%$ w/w respectively (Table 1 and Figure 2).

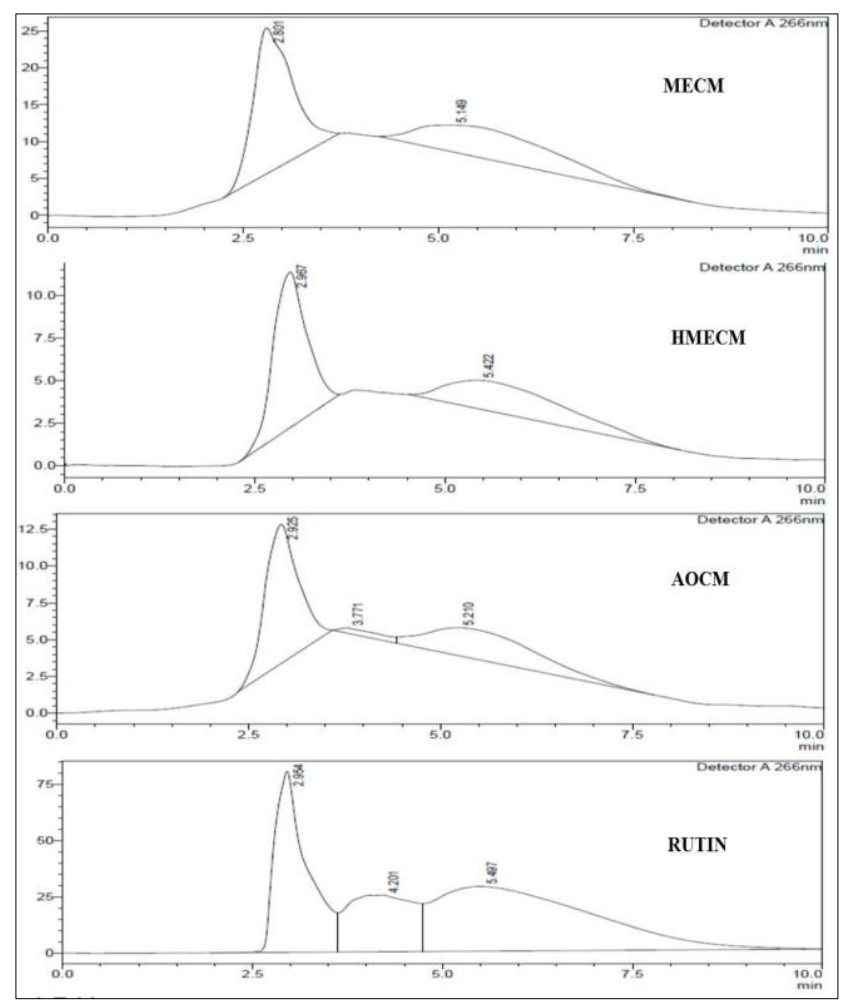

Figure 3: HPLC analysis on CM fruits extracts and standard rutin.

CM fruits extract at $266 \mathrm{~nm}$ showed well resolved peaks at retention time in minutes of MECM (2.801, 2.669), HMECM $(2.967,2.804)$ and AQCM (2.925, 2.669) in comparison to rutin (2.954) and quercetin (2.680) at 372 $\mathrm{nm}$. Quantitative amounts of standards and extracts were found to be MECM (45.2, 8.6), HMECM $(21,8.9)$ and $\operatorname{AQCM}(31.2,7.4)$ respectively in \% (Figure 3,4 ). 


\section{Acute toxicity}

\section{Mortality/Viability/Clinical signs/Body weights}

CM fruits extracts were reported therapeutically safe up to $2000 \mathrm{mg} / \mathrm{kg} \mathrm{B}$.W. and all rats had gained body weight by day 14 as compared to day 0 .

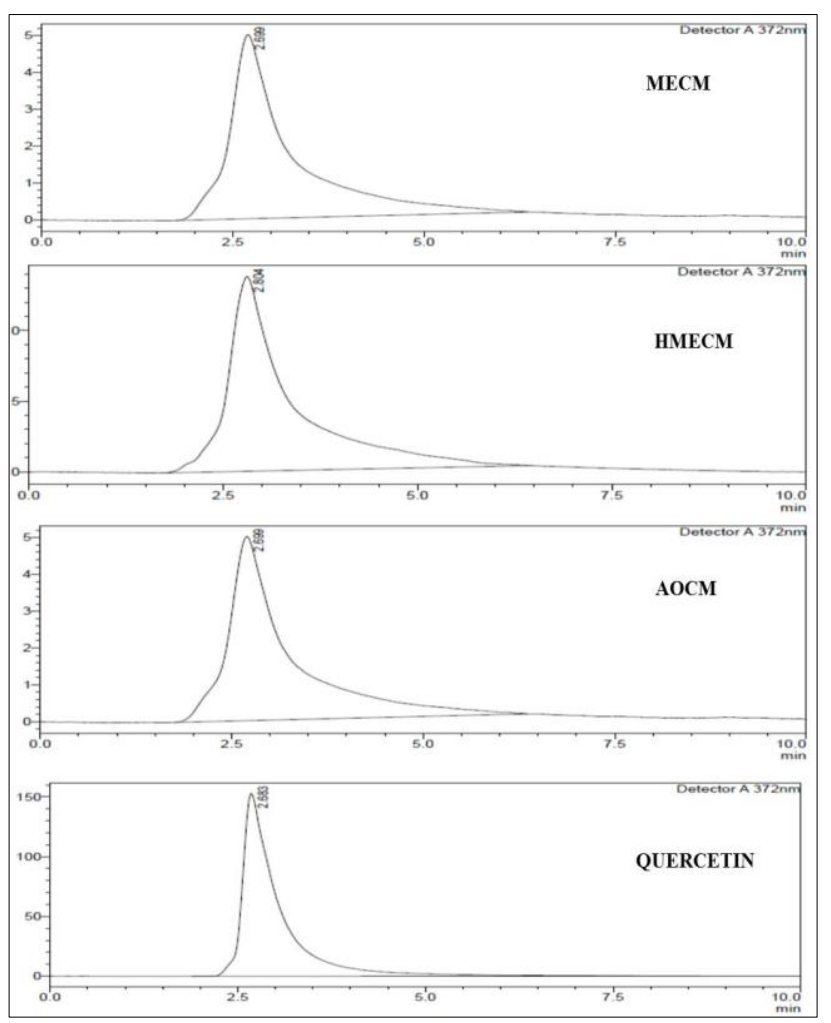

Figure 4: HPLC analysis on CM fruits extracts and standard quercetin.

\section{Animal models}

$H A$

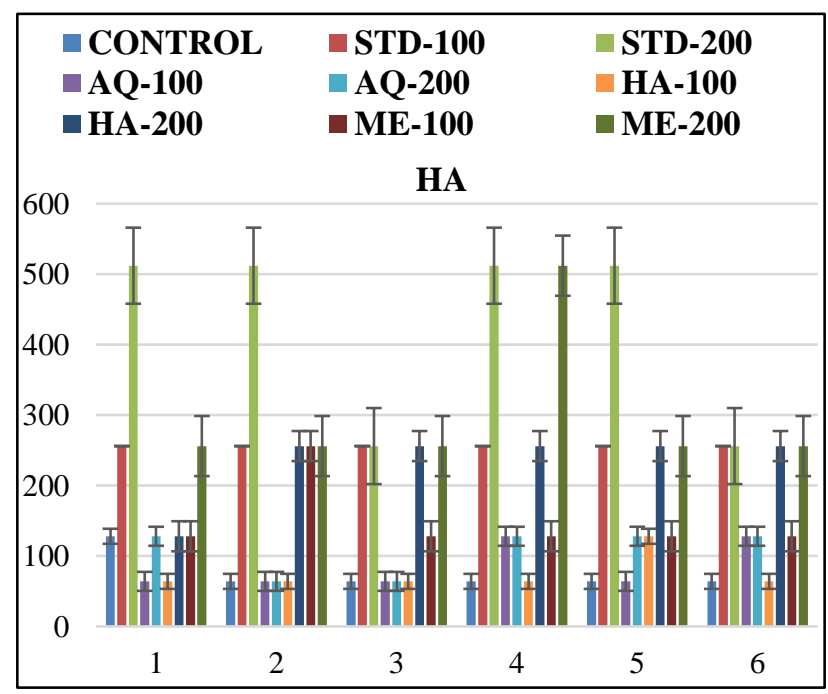

$\mathrm{CM}$ fruits extracts at $200 \mathrm{mg} / \mathrm{kg}$ showed significant activity and no activity at $100 \mathrm{mg} / \mathrm{kg}$ as comparable to the standard (Figure 5).

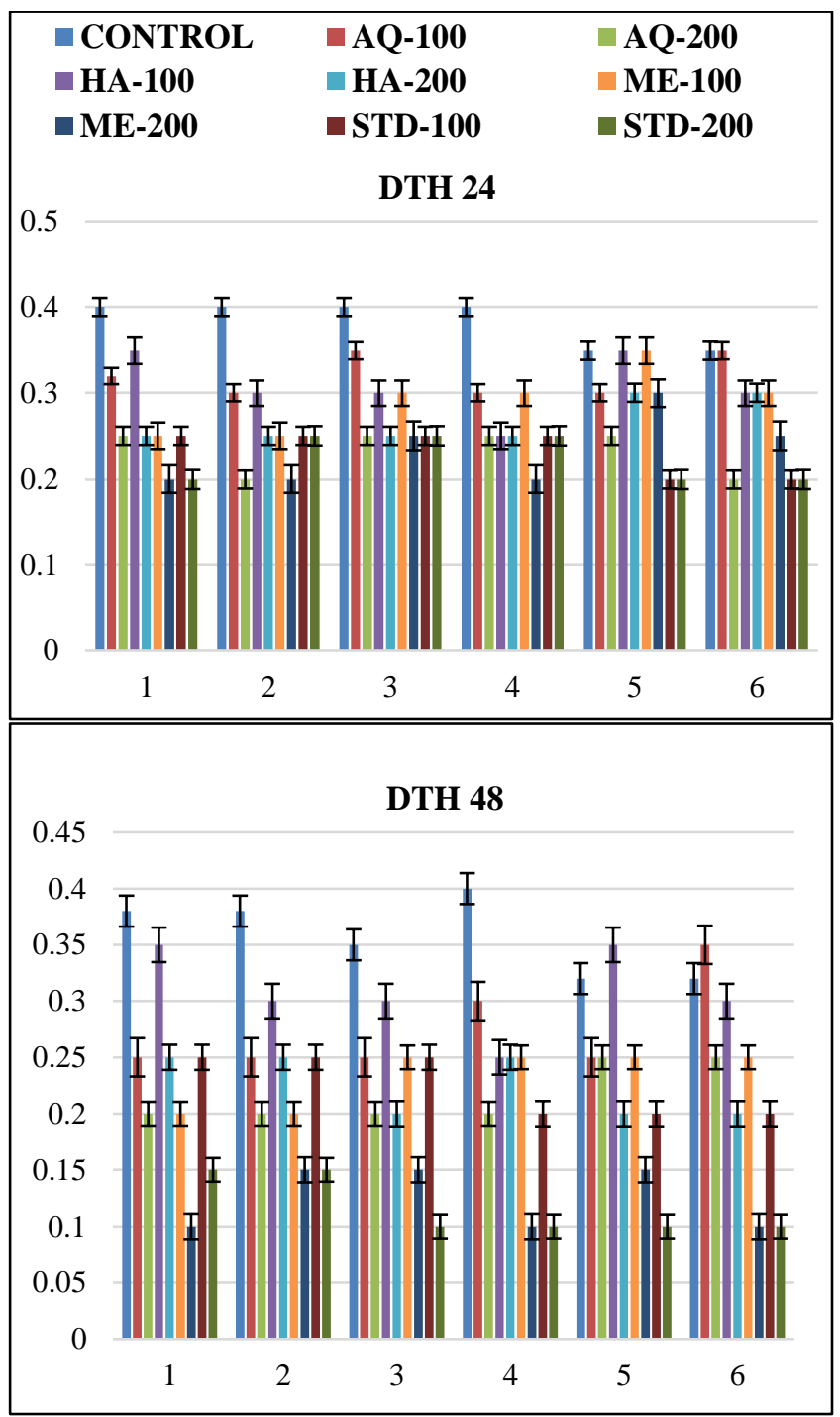

Figure 6: DTH studies on CM fruits extracts.

DTH

CM fruits extract showed dose dependent decrease in paw edema after $48 \mathrm{~h}$ of challenge at 100 and $200 \mathrm{mg} / \mathrm{kg}$ when compared to control group (Figure 6).

\section{Antioxidant activity}

CM fruits extract showed $\mathrm{IC}_{50}$ value of MECM (0.338), HMECM (0.905) and AQCM (2.122) as compared to standard (0.132) (Figure 7).

\section{In vitro screening of the CM fruits}

$\mathrm{CM}$ fruit extracts were found to be unresponsive on selected cell lines at different concentrations studied as

Figure 5: HA titre on CM fruit extracts. 
compared to standard drug Adriamycin. A, B and C are AQCM, HMECM and MECM respectively (Figure 8).

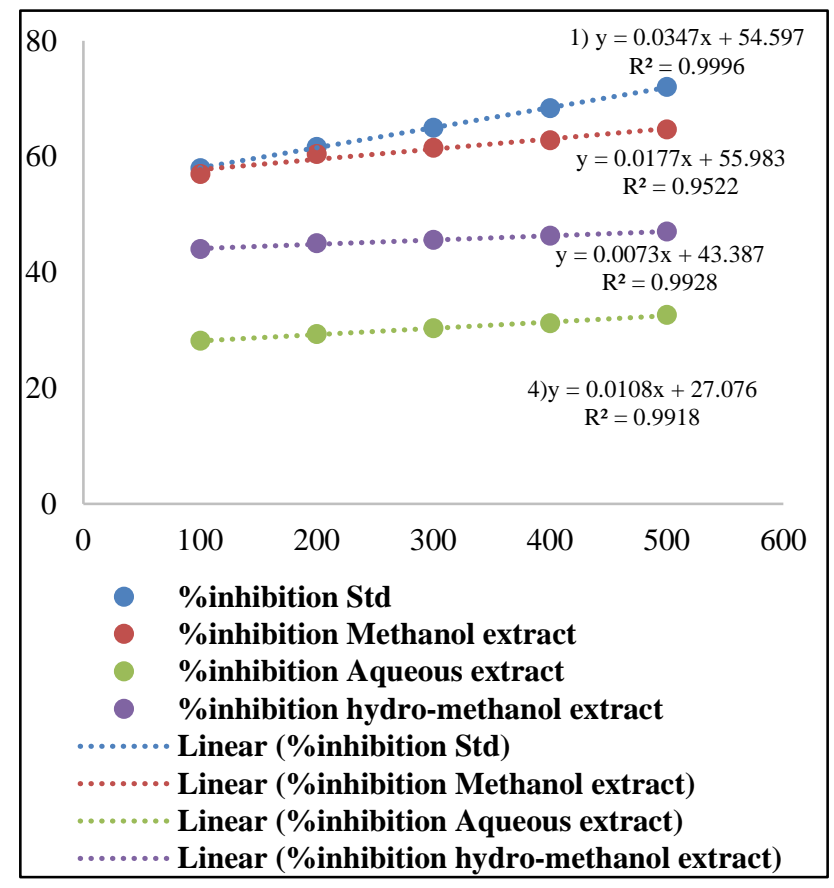

Figure 7: DPPH studies on CM fruits extracts.

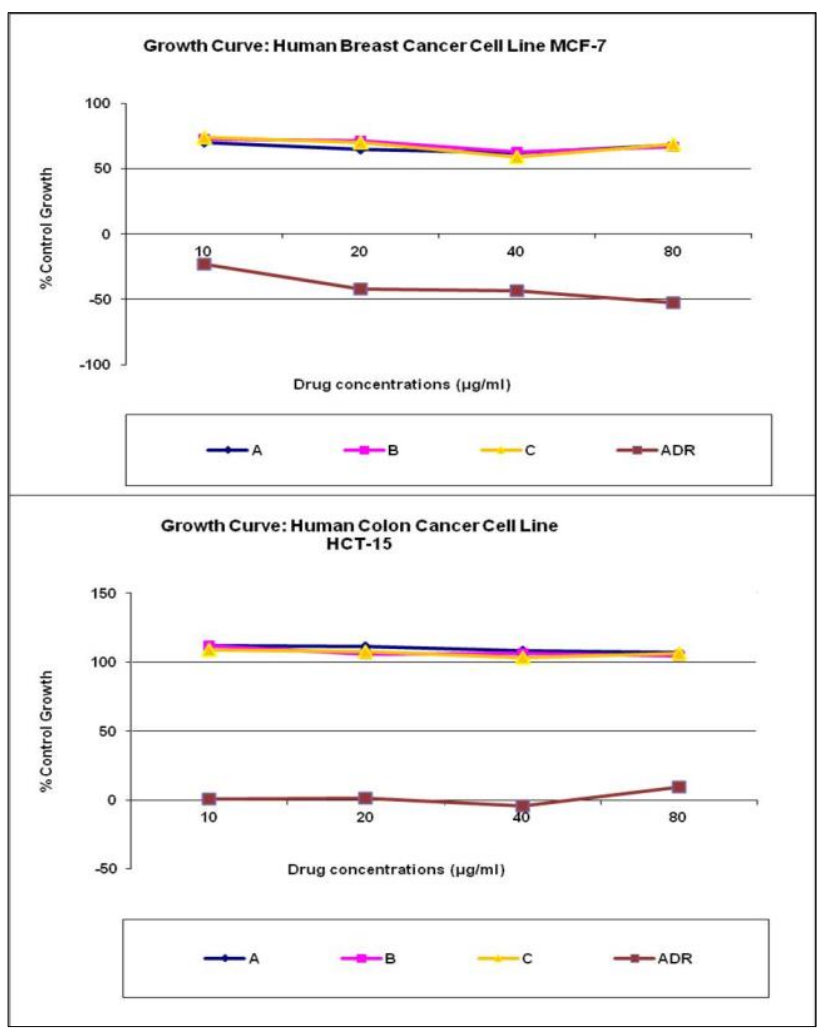

Figure 8: Cell line studies on CM fruits extracts.

\section{Potato disc assay on CM fruits}

CM fruits extract were found to be unresponsive on the selected assay method.

\section{DISCUSSION}

$\mathrm{CM}$ fruit extracts have been found positive for presence of phytoconstituents such as rutin and quercetin identified by combined chromatographic techniques such as HPTLC and HPLC. In vivo HA titre and DTH response immuno models were found satisfactory correlating to the above stated phytochemical results. However, an attempt for screening of the fruits extracts by potato disc assay and in vitro cell lines posed negative outcome (Figure 1).

In past research studies, aqueous and ethanolic extracts of dried fruits of Capparis moonii fruits showed significant in vitro phagocytic stimulation of lysosomal enzyme, myeloperoxidase activity and nitric oxide in peritoneal mouse macrophages, propagating the surge for in vivo studies. ${ }^{4}$ The research in the paper has been one of its first attempts to screen the selected plant extracts (MECM, HMECM and AQCM) for its in vivo immunomodulatory potential with phytochemical identification of rutin and quercetin by chromatographic studies.

HPTLC has been regarded as one of the most versatile and result based technique in case of identification of phytoconstituents present in plants. ${ }^{10,20}$ In current research studies, CM fruit extracts showed the presence of rutin and quercetin when compared with standard based on maximum $\mathrm{R}_{\mathrm{f}}$ value, areas and formula calculations. HPLC has added an insight to the existing list of chromatographic techniques by providing clear view point of peaks compared on the basis of retention time. ${ }^{10}$ In HPLC chromatograms, rutin and quercetin in the fruit extracts were interpreted based on its comparison with the standard.

Lymphoreticular system is a complex network of lymphoid cells and reticuloendothelial components. The lymphoid cells (lymphocytes and plasma cells) are basically concerned with the specific immune response. In response to the antigen attack irrespective of its nature, there is an exaggeration of humoral antibody (HAI) or cellular mediated (CMI) immunity. Lymphocytes are small, round cells located in peripheral blood, lymph, lymphoid organs and allied tissues nearby its vicinity area. The cortical follicles and medullary cods contain B lymphocytes whereas between these two regions there is an ill-defined intermediate zone which contains $T$ lymphocytes. Activated T cells produce specific activation products (lymphokines) and initiate CMI and B-cells to divide, converting themselves into plasma cells which synthesize immunoglobulins. Due to the ethical considerations in the current decades, it is not possible to perform investigation of immune system related infections in humans and hence, alternative was to use rats species and SRBC's cells as antigens. B-cells when bind to SRBCs cells coated with antibody and complement leads to EAC rosettes formation due to the presence of $\mathrm{C}-3$ receptor $(\mathrm{CR}$ 2) on B cell surface. T cells bind to SRBC's cells forming rosettes by CD2 antigen., ${ }^{2,31-25}$ High antibody titre values (Figure 5) and marked decrease in the paw volume (48 h) 
(Figure 6) correlates to B and T lymphocytes respectively suggesting probable immunomodulatory prospects of $\mathrm{CM}$ fruit extracts.

Witnessing the population statistics in India more patients noticed to be under the dilemma of breast and colon cancer. Further breast cancer was more prevalent among women and colon among men. ${ }^{26-28}$ Considering these facts, an attempt has was being made to check whether the fruits extracts are having antioxidant potential and if results found to be positive (Figure 7), further screen them for its cancer potentiality. For this purpose, SRB assays were preferred (fluoresces with laser excitation at $448 \mathrm{~nm}$ ) which shows quick, stable, uniform and reliable results (based on single cell principle as compared to MTT assays. ${ }^{29}$ The basic reason behind the selection of the cell lines were wide acceptance, utility in research area, hormone sensitivity through estrogen receptor and ability to activate p53 in order to judge the stage of cancer. CM fruit extracts results on selected cells lines (MCF 7 and HCT 15) were found to be unsatisfactory (Figure 8).

\section{CONCLUSION}

The present investigation suggests that $\mathrm{CM}$ fruits extracts exerts significant immunomodulatory activity.

\section{ACKNOWLEDGEMENTS}

Authors would like to thank to the College Management and Principal, Dr. Supriya Shidhaye, VESCOP who provided us all the facilities to screen the plant for immunomodulatory activity with the aid of contingency grant, Anchrom Research Laboratories Pvt. Ltd. for HPTLC studies and Advanced Centre for Treatment Research and Education in Cancer for anticancer studies.

Funding: No funding sources Conflict of interest: None declared

Ethical approval: The study was approved by the Institutional Ethics Committee

\section{REFERENCES}

1. Doshi GM, Une HD. In vitro cytotoxicity studies on Carissa congesta, Polyalthia longifolia, and Benincasa hispida extracts by Sulforhodamine B assay method. Int J Gr Pharm. 2015;9(3):157-61.

2. Ananthanaryan R, Paniker JCK. Immunodeficiency diseases. In Text of Microbiology Part II. $6^{\text {th }} \mathrm{Ed}$. Orient Longman Limited Publishing House. India; 2000:142-149.

3. Doshi GM, Une HD. Screening of Polyalthia longifolia Leaves as Potential Immunomodulatory Target. Int J Pharmacol. 2015;11(2):106-13.

4. Vanita GK, Brijendra J, Pramila Y. Evaluation of invitro immunomodulatory activity of aqueous and ethanolic extract of Capparis moonii. Int J Pharm Bio Sci. 2013;4(2):344-52.
5. Mishra N, Tomar PC, Lakra N. Medicinal and food value of Capparis- a harsh terrain plant. Ind J Trad Knowl. 2007;6(1):230-8.

6. Khandelwal KR. Practical PharmacognosyTechniques and Experiments.10 ${ }^{\text {th }}$ Ed. Nirali Prakashan Pune. India; 2000:149-56.

7. Kokate CK. Practical Pharmacognosy. $2^{\text {nd }}$ Ed. India: Vallabh Prakashan, New Delhi; 1989:111-4.

8. Alali F, Tawaha K, El-Elimat T, Syouf M, El-Fayad M, Abulaila K, et al. Antioxidant activity and total phenolic content of aqueous and methanolic extracts of Jordanian plants: an ICBG project. Nat Prod Res. 2007;21:1121-31.

9. Doshi GM, Chaskar PK, Zine SP, Une HD. Solicitation of HPLC and HPTLC for determination of rutin from Polyalthia longifolia. Pharmacog Res. 2014;6(3):234-9.

10. Harborne JB. Phytochemical methods: A guide to Modern Techniques of Plant Analysis. $3^{\text {rd }}$ Ed. Springer (India) Private limited Publication House,New Delhi; 2005:11-12.

11. Gupta SM, Shivaprasad HN, Kharya MD, Rana AC. Immunomodulatory activity of the Ayurvedic Formulation "Ashwagandha churna". Pharm Bio. 2006;44:263-5.

12. Bader JM. Identification of T lymphocytes. In: Glase J C (Eds.) Tested Studies for Laboratory Teaching, Kendall; Hunt Publishing Company, USA;1997(18):113-123.

13. OECD Guideline for Testing of Chemicals: Acute Oral Toxicity - Acute Toxic Class Method: Adopted: 17 $7^{\text {th }}$ Ed. 2001:1-14.

14. Shukla S, Mehta A, John J, Mehta P, Vyas SP. Immunomodulatory activities of ethanolic extract of Caesalpinia bonducella seeds. J Ethno pharmacol. 2009;125:252-6.

15. Vogel GH. In: Drug Discovery and Evaluation, Pharmacological Assays. Chapter I: Methods for testing immunological factors, $2^{\text {nd }}$ Ed. India; 2002:788-820.

16. Stankovic MS. Total phenolic content, flavonoid concentration and antioxidant activity of Marrubium peregrinum L. extracts. Kragujevac J Sci. 2007;33:6372.

17. Skehn P, Storeng R, Scudiero A, Monks J, McMohan D, Vistica D, et al. New colorimetric cytotoxicity assay for anticancer drug screening. J Nat Cancer Ins. 1990;82:1107.

18. Vanicha V, Kanyawim K. Sulforhodamine B colorimetric assay for cytotoxicity screening. Nature Protocols. 2006;1:1112-6.

19. Coker PS, Radecke, J, Guy, G, Camper ND. Potato disc tumor induction assay: A multiple mode of drug action assay. Phytomedicine. 2003;10:133-8.

20. Nagore DH, Patil PS, Kuber, VK. Comparison between High Performance Liquid Chromatography and High Performance Thin Layer Chromatography for determination of Diosgenin from the fenugreek seeds. Int J Gr Pharm. 2012;6(4):315-20. 
21. Barar FSK. In: Essentials of Pharmacotherapeutics. Chapter: Immune System, Immunosuppressants and Immunostimulants. $5^{\text {th }}$ Ed. S Chand and Company Limited, New Delhi; 2009:489-492.

22. Benacerraf B. A hypothesis to relate the specificity of T lymphocytes and the activity of I region specific IR genes in macrophages and borrower lymphocytes. J Immunol. 1978;120:1809-32.

23. Goodman and Gilman. In: The Pharmacological Basis of Therapeutics. Edited by Laurence L. Bruton and John S Lozo, Keith L Parker. Chapters: Pharmacotherapy of Asthma by Bradley JU and Immunodulators Immunosuppressants, Tolerogens and Immunostimulants. $11^{\text {th }}$ Ed. Mc-Graw Hill. New Delhi; 2005:717-736.

24. Miller LE In: Ludke HR, Peacock JE, Tomar RH (Eds.), Lea and Febiger. Manual of Laboratory Immunology. London; 1991:1-18.

25. Nair PP, Turjman N, Kessie G, Calkins B, Goodman GT, Davidovitz H, et al. Diet, nutrition intake, and metabolism in populations at high and low risk for colon cancer. Am J Clin Nut. 1984;40:927-30.

26. Doshi GM, Une HD. Carissa congesta Wight and Benincasa hispida (Thunb.) Cogn. as Budding
Immunomodulatory Targets. Ind $\mathbf{J}$ Exp Bio. 2016;54(10):650-8.

27. Nautiyal J, Kanwar SS, Yu Y, Majumdar APN. Combination of dasatinib and curcumin eliminates chemo-resistant colon cancer cells. J Mol Sig. 2011;6:1-11.

28. Parasramka MA, Gupta SV. Synergistic effect of garcinol and curcumin on antiproliferative and apoptic activity in pancreatic cancer cells. J Oncol. 2012;2012:709-39.

29. Keepers PY, Piazo PE, Peters JG, Otte JVA, Winogard B, Pinnedo HM. Comparison of the Sulforhodamine B protein and Tetrazolium (MTT) Assays for in vitro chemosenstivity testing. Eur J Cancer. 1991;27(7): 897-900.

Cite this article as: Doshi GM, Pawar MK, Chavda $\mathrm{KH}$. Quantification of rutin and quercetin by HPTLC/HPLC and in vitro immunomodulatory and anticancer activities of Capparis moonii fruits extracts. Int J Basic Clin Pharmacol 2018;7:153-61. 